\title{
Jak nie tłumaczyć gier na rosyjski. Analiza lokalizacji gry Książę $i$ Tchórz z języka polskiego na język rosyjski
}

How not to translate games into Russian. An analysis of the localisation of the game "Książę i Tchórz" from Polish into Russian

\section{Dominik Kudta}

Uniwersytet Warszawski | dominik123kudla@gmail.com ORCID: 0000-0001-5738-9852

\begin{abstract}
The article depicts the question of translation errors found in the linguistic localisation of video games. A Polish computer game Książe i Tchórz (Metropolis, 1998) and its Russian version (Галадор - Проклятие принца, 7-ой волк, 1999) have been chosen to present the most important aspects of the aforementioned issue. Special attention was also drawn to differentiating between the notions of linguistic localisation and translation of video games, classifying crucial errors in this type of translation and their possible reasons.
\end{abstract}

Keywords: video games, linguistic localisation, translation errors, pointand-click 



\section{Wstęp}

Gry wideo stanowią medium multimodalne, łączące w sobie kilka rodzajów tekstów. Sprawia to, że ich lokalizacja językowa wymaga od tłumacza kompleksowego podejścia i szczególnej uwagi. Pomimo tego przekłady takie nie są wolne od usterek. W niniejszym artykule postaram się przybliżyć, jakich błędów należy się wystrzegać w procesie lokalizacji z języka polskiego na rosyjski. Praca składa się z pięciu części. Pierwsza zaprezentuje kluczowe pojęcia z zakresu lokalizacji językowej gier wideo. Następnie przedstawiona zostanie klasyfikacja najistotniejszych błędów występujących w tego rodzaju tłumaczeniu. Trzecia część stanowi opis gry wybranej do pokazania błędów popełnianych w omawianym procesie - Książę i Tchórz. Następnie omówione zostaną przekład tej gry na język rosyjski oraz występujące w nim usterki.

\section{Lokalizacja językowa gier wideo}

W rozumieniu potocznym wyrażenia „tłumaczenie gier” i „lokalizacja językowa gier" są używane zamiennie. Jednak translatolodzy rozgraniczają ich zastosowanie. Zdaniem większości z nich (np. Kuipers, 2010; Czech, 2013; O’Hagan, Mangiron, 2013; Bernal-Merino, 2015) lokalizacja językowa jest przedsięwzięciem szerszym, a przekład językowych elementów składających się na grę stanowi tylko jedną z części takiego przedsięwzięcia. O’Hagan i Mangiron określają lokalizację gier wideo jako:

ogół wielu różnorodnych procesów służących przekształceniu oprogramowania gry stworzonego w jednym kraju tak, aby przybrało ono postać dostosowaną do regionów docelowych, uwzględniającą nowy zespół środowisk użytkowników, co niesie za sobą konkretne implikacje językowe, kulturowe oraz techniczne (2013, s. 19).

Wielu badaczy wskazuje, że ta dziedzina tłumaczeń łączy w sobie elementy przekładu audiowizualnego, np. konieczność synchronizacji ruchów warg postaci z dubbingiem czy zmagania z ograniczeniami dotyczącymi długości wyświetlanych podpisów, oraz lokalizacji oprogramowania, np. pracę z kodem źródłowym lub znaczniki pojawiające się w tekście oryginalnym (Kuipers, 2010; Drab, 2014). Część translatologów 
klasyfikuje przekłady takiego typu jako rodzaj tłumaczeń audiowizualnych (np. Drab, 2014). Obecnie coraz więcej przekładoznawców (np. Czech, 2013; O’Hagan, Mangiron, 2013; Bernal-Merino, 2015) skłania się ku przekonaniu, że translacje szeroko pojętych gier wideo powinny być uznawane za odrębny gatunek tłumaczeń, ponieważ w tym rodzaju lokalizacji językowej w ramach jednego projektu ma zastosowanie wiele aspektów różnych wyodrębnionych wcześniej dziedzin tłumaczenia.

Lokalizacja gier różni się od lokalizacji innych kategorii oprogramowania ze względu na odmienny charakter interakcji użytkownika $\mathrm{z}$ tym medium. Obcując z nim - w przeciwieństwie do oprogramowania użytkowego - odbiorca czuje się emocjonalnie związany z wynikiem interakcji (Juul, 2005, s. 23). Często wymienianym kryterium odrębności lokalizacji gier jest odzwierciedlenie oryginalnej rozgrywki (ang. gameplay), tj. ogółu przeżyć odczuwanych przez odbiorcę w kontakcie z daną grą, przez zlokalizowaną wersję tej gry (Kuipers, 2010, s. 79; Bernal-Merino, 2015, s. 282). Główny cel omawianego procesu według O’Hagan i Mangiron (2013, s. 17) stanowi przekazanie - w możliwie wierny sposób doświadczenia związanego z grą i dostosowanie go do rynku docelowego.

Nie zawsze jednak na tym polega cel nadrzędny tłumaczy pracujących nad nową wersją językową danej gry. Ważnym elementem takiego przekładu jest transkreacja, czyli tłumaczenie oddające bardziej charakter niż konkretną treść informacyjną tekstu wyjściowego, co wiąże się z tworzeniem pewnych elementów gry na nowo. Praktyka ta była powszechna w latach 80. i 9o. XX wieku, gdy zlokalizowane wersje językowe produkcji multimedialnych w znaczny sposób odbiegały od oryginału, ponieważ głównym celem było zapewnienie jak największej rozrywki - poprzez żartobliwość ${ }^{\text {. }}$

Ze względu na różnice kulturowe konkretna gra w pierwotnej wersji może zawierać treści, które należą do strefy tabu w innej kulturze.

1 O’Hagan i Mangiron (2013, s. 53-54) podają przykład zmiany kwestii wypowiadanej przez księżniczkę na końcu gry Super Mario Bros 3. W japońskiej wersji kwestia ta brzmiała: „Dziękuję! Pokój powrócił do Krainy Grzybów. Koniec!”, podczas gdy tłumaczenie na rynek amerykański wyglądało następująco: „Dziękuję. Ale nasza Księżniczka jest w innym zamku!... Tylko żartowałam! Ha ha ha! Pa pa". Uwaga dodana w wersji angielskiej stanowi aluzję do - często pojawiającej się w poprzedniej części gry - sekwencji, w której okazywało się, że następczyni tronu, ratowana przez protagonistę, znajduje się jednak gdzie indziej. 
Niekiedy sytuacja tego typu wiąże się z modyfikacjami świata przedstawionego, jak usunięcie lub dodanie jego elementów czy nawet zmiany w fabule. Przykładem takich przekształceń jest wymienione przez O’Hagan i Mangiron (tamże, s. 208) usuwanie elementów o charakterze erotycznym z gier sprzedawanych na rynkach arabskich, co łączyło się z pominięciem części fabuły.

\section{Błędy tłumaczeniowe w lokalizacji gier wideo}

Ponieważ przekład gry wideo na inne języki jest procesem złożonym, również niedociągnięcia i uchybienia mogą pojawić się w nim na wielu poziomach.

Najogólniej niedoskonałości translacji dzieli Dybiec-Grajer (2013), która wymienia błędy bezwzględne (jednoznacznie naruszające normy lingwistyczne lub przekładowe) oraz względne (o dyskusyjnej akceptowalności). Ogólną klasyfikację proponuje również Dzierżanowska (1988), wyróżniając błędy językowe oraz tłumaczeniowe. Pierwsze z nich są odchyleniami od normy danego języka na poziomie ortografii, gramatyki (morfologii, składni) oraz szyku zdania. Do drugiej grupy (nazywanej przez Hejwowskiego [2001, s. 139] błędami tłumaczeniowymi sensu stricto) zalicza badaczka usterki leksykalne oraz te związane z brakiem adekwatności stylistycznej, semantycznej lub kontekstowej.

Karczewska (2001) dzieli błędy tłumaczeniowe na te sytuujące się w planie wyrażenia oraz te pojawiające się w planie treści. W pierwszej $\mathrm{z}$ opisanych kategorii wymienia usterki leksykalne (zastosowanie niewłaściwego ekwiwalentu danego słowa w języku docelowym, niedoskonałość terminologiczna lub zjawisko faux amis - „fałszywych przyjaciół”) oraz modyfikacje w strukturze zdaniowo-znaczeniowej wywołane użyciem niewłaściwego ekwiwalentu danego słowa (gdy „tłumacz swobodnie i oryginalnie próbuje rekonstruować sens zdania" [tamże, s. 132]) bądź środków językowych należących do niewłaściwego rejestru stylistycznego. Błędy w planie treści wolno określić jako niedoskonałości w przekładzie intertekstualności dzieła oryginalnego. Mogą one wiązać się z nieprzekazaniem wiadomości dodatkowych, znanych w kulturze wyjściowej, ale nieznanych odbiorcy wersji docelowej, lub zawarciem informacji 
redundantnych, czyli takich, które są powszechnie znane w kulturze docelowej. Trzeci rodzaj błędów tłumaczeniowych wymieniany przez translatologów stanowią luki w przekładzie spowodowane pominięciem istotnych semantycznie elementów tekstu oryginalnego, np. wyrazów, wyrażeń lub nawet zdań (Grucza, 1978; Karczewska, 2001; Pieńkos, 2003).

Błędy w lokalizacji językowej wykraczają poza zarysowany tutaj zakres błędów tłumaczeniowych i oprócz nich obejmują szereg zagadnień technicznych związanych z grami wideo jako medium. Najważniejszymi z tych usterek są niedopasowanie podpisów do limitów liczby znaków, wybór nieodpowiedniej czcionki, wskutek czego albo tekst jest nieczytelny, albo nie wyświetlają się poprawnie znaki charakterystyczne dla danego języka, brak synchronizacji podpisów z dubbingiem, brak użycia terminów powszechnie stosowanych w języku gier, błędy typograficzne polegające na przestawieniu lub omylnym wstawieniu znaków w słowach (tzw. literówki) oraz niedostosowanie konkretnego fragmentu tłumaczenia do zmieniających się warunków gry (Czech, 2013; O’Hagan, Mangiron, 2013; Bernal-Merino, 2015).

Przedstawiona klasyfikacja ma charakter poglądowy, gdyż w wielu przypadkach trudno przypisać dany błąd jednoznacznie do konkretnej kategorii. Wynika to z faktu, że często drobniejsze usterki mogą prowadzić do pojawienia się znacznie poważniejszych nieścisłości w tekście docelowym.

\section{Książę i Tchórz}

Stworzona w 1998 roku przez warszawskie studio Metropolis (międzynarodowym wydawcą była niemiecka firma TopWare) gra Książę $i$ Tchórz stanowiła jedną z pierwszych polskich gier przygodowych. Przez wielu graczy jest uważana za część klasyki w swoim gatunku (TVGRYpl, 2017). Ukazała się również w trzech innych językach - niemieckim, angielskim oraz rosyjskim.

W trakcie rozgrywki wcielamy się w plebejskiego młodzieńca, Galadora, którego żądza przygód skłania do podpisania osobliwego kontraktu z diabłem. Chłopak zgadza się na przeniesienie swojej duszy w ciało księcia bajkowej krainy, gdzie toczy się akcja gry. Moment tej zamiany trudno jednak nazwać udanym, gdyż dochodzi do niej w chwili, gdy następca 
tronu miał stanąć w szranki z dwa razy wyższym od siebie rycerzem. Nieszczęsny Galador salwuje się ucieczką, przez co sprowadza na siebie gniew króla. Celem gracza jest naprawienie całej tej sytuacji, czyli powrót bohatera do własnego ciała, co będzie wymagało nie lada wysiłku.

Jeśli chodzi o sterowanie, to Książę i Tchórz należy do gatunku point-and-click (ang. 'wskaż i kliknij'). Kierowanie postacią sprowadza się do sygnalizowania kursorem, w które miejsce na ekranie ma się ona udać, oraz do wyznaczania - prawym przyciskiem myszy -przedmiotów lub osób i wybierania możliwej interakcji z menu podręcznego. Jak w każdej produkcji multimedialnej z tego gatunku, ważną rolę odgrywają rozmowy z napotkanymi postaciami oraz wykorzystywanie i łączenie znajdowanych rzeczy.

Bardzo istotnym elementem Księcia $i$ Tchórza są liczne zabawy słowne i odwołania kulturowe. Dotyczą one zarówno realiów Polski lat 90. XX wieku, jak i innych tekstów kultury, zwłaszcza powieści fantasy. Na różnych etapach rozgrywki napotykamy postacie, przedmioty oraz historie zaczerpnięte lub zainspirowane Władcą Pierścieni Johna R. R. Tolkiena oraz sagą o Geralcie z Rivii autorstwa Andrzeja Sapkowskiego. Na polską oprawę dźwiękową Księcia i Tchórza składa się dubbing o bardzo dobrej obsadzie (postaciom głosów użyczyli m.in. Kazimierz Kaczor czy Arkadiusz Jakubik) oraz oddająca atmosferę poszczególnych lokacji muzyka autorstwa Karima Martusewicza, Juliusza Gyuli Grubera i Adama Skorupy (znanego również ze stworzenia ścieżki dźwiękowej do dwóch pierwszych gier z serii Wiedźmin). Zaletami sprawiającymi, że produkcję tę uznać można za skierowaną do odbiorców z różnych grup wiekowych, są też miła dla oka rysunkowa grafika świata przedstawionego oraz fakt, że w toku akcji co prawda pojawiają się żarty bardziej zrozumiałe dla osób dorosłych, ale w tak zawoalowanej formie, że nie gorszą młodszych użytkowników.

\section{5. Галадор - Проклятие Принца}

Gra Książę i Tchórz została przetłumaczona na język niemiecki (Galador - Der Fluch des Prinzen), angielski (Curse of the Prince) i rosyjski (Галадор - Проклятие принца). Ponieważ w tworzeniu produkcji brał 
udział niemiecki producent, to wydanie stoi również na wysokim poziomie lingwistycznym. Wersja angielska powstała nieco później niż polska i niemiecka. W przeciwieństwie do nich nie jest to pełna lokalizacja językowa. Jedynie podpisy i tekstowe elementy graficzne występujące w grze zostały przetłumaczone na język angielski, a głosy bohaterów pozostawiono w języku niemieckim. W 2014 roku ukazał się jeszcze jeden przekład na język angielski (The Prince and the Coward), który również stanowi niepełną lokalizację, tym razem opartą na polskiej wersji dźwiękowej. Łukasz Wątka, student Politechniki Gdańskiej, zdobył dofinansowanie w ramach programu Google Summer of Code na stworzenie anglojęzycznej i kompatybilnej ze współczesnymi systemami operacyjnymi wersji gry rozpowszechnianej za pośrednictwem strony ScummVM (Kutera, 2014). Tłumaczenie i konwersja zostały ukończone i upublicznione, jednak obecnie gra nie jest dostępna w tej formie.

Jak wskazują Donovan (2010) oraz O'Hagan i Mangiron (2013), jedną z powszechnych w latach 80. i 9o. XX wieku praktyk prowadzących do zaistnienia lokalnych wersji językowych był ROM-hacking, czyli modyfikowanie danych nieprzeznaczonych do ingerencji (ROM = ang. read-only memory - 'pamięć wyłącznie do odczytu'), dotyczących różnych aspektów gry, z których najczęstszy stanowiły elementy językowe; zazwyczaj były to oczywiście tłumaczenia amatorskie. Często działalność tego typu miała (i ma do dziś) charakter non-profit, ale mogła być związana z powstawaniem pirackich kopii danej gry.

Tak działo się w przypadku zdecydowanej większości zagranicznych produkcji multimedialnych wydawanych w ZSRR, a później w Federacji Rosyjskiej do około 2005 roku (Mosin, 2015). Przekłady tego rodzaju wykonywały grupy lokalizacyjne, jak Фаргус (Fargus), Russian Group, Наша марка (Nasza Marka), Триада (Triada), 7-ой волк (Siódmy Wilk). Lokalizacje owe mogły powstawać bez żadnej zgody twórców oryginałów ze względu na długie nieobowiązywanie reguł prawa międzynarodowego w Rosji i być może również na początkową nieświadomość opisanego procederu wśród producentów.

Rusyfikacje omawianego typu w żargonie rosyjskich graczy doczekały się pogardliwego przydomka „русефекация” („rusefekacija” - 'rusefekacja') (Lurkmore.to, 2017). Charakteryzuje je znaczna liczba błędów językowych oraz niedbałość wykonania tłumaczenia, objawiająca się 
m.in. licznymi literówkami, nieścisłościami czy pominięciami względem wersji oryginalnej ${ }^{2}$.

Rosyjski przekład Księcia $i$ Tchórza powstał w 1999 roku, czyli dość szybko po ukazaniu się edycji polskiej i niemieckiej. Twórcami tej lokalizacji, obejmującej zarówno napisy, jak i głosy postaci, są członkowie jednej z wymienionych grup - studia 7-ой волк. Jak sugeruje tytuł tej odsłony (tak samo jak w wersji niemieckiej brzmiałby on po polsku: Galador - Klątwa księcia) oraz wiele z zastosowanych w niej rozwiązań tłumaczeniowych, bazowano w niej raczej na niemieckiej niż na polskiej wersji językowej. Może w tym miejscu powstać pytanie, która z tych wersji powinna być uważana za oryginalną (prymarną). W końcu gra powstała i ukazała się dzięki współpracy dwóch podmiotów, pochodzących z dwóch różnych krajów. Jednakże fakt, że scenariusz, mechanikę oraz grafikę gry stworzył polski zespół, wskazuje na prymarny charakter wariantu rodzimego. $\mathrm{Z}$ tego względu można stwierdzić, że strategia obrana przez twórców omawianej „rusefekacji” była w tym przypadku błędna. $\mathrm{Z}$ wielu innych rodzajów przekładu wiadomo, że dokonywanie go na podstawie wcześniejszego tłumaczenia nie jest prawidłowym rozwiązaniem. Jednak z uwagi na różnego rodzaju okoliczności (tutaj był to najprawdopodobniej brak dostępu do polskiej wersji językowej) często praktyka taka znajduje zastosowanie ${ }^{3}$.

Rosyjska wersja Księcia i Tchórza została wybrana do przedstawienia zagadnienia błędów w lokalizacji językowej gier wideo z języka polskiego na język rosyjski z uwagi na reprezentatywność tej produkcji dla gatunku point-and-click i na staranne przygotowanie polskiej wersji językowej (zob. opis cech gry zawarty w sekcji 4). Ponadto tłumaczenie owo stanowi przykład amatorskich lokalizacji językowych, które nie były dotychczas szeroko omawiane w polskiej literaturze translatorycznej. Ksiq̨żęi Tchórz jest też jedną z pierwszych gier przetłumaczonych z polskiego na rosyjski,

2 Obecnie, gdy rosyjskie lokalizacje gier wideo nie odbiegają jakościowo od poziomu znanego np. na rynku polskim, część graczy z nostalgią wspomina czasy tej właśnie „rusefekacji" (Ujutnyj podwalczik, 2015).

3 Innym przykładem może być tłumaczenie symultaniczne na określony język na podstawie tego wykonywanego na angielski z języka, w jakim wypowiada się mówca. Może to wynikać z braku środków, miejsca lub czasu na zapewnienie tłumaczy kabinowych we wszystkich możliwych kombinacjach na wydarzeniach międzynarodowych i wielojęzykowych. 
dlatego może stworzyć dobrą podstawę dla przyszłych badań diachronicznych, porównujących lokalizacje z lat 9o. XX wieku ze współczesnymi.

\section{Błędy w lokalizacji gry Książę i Tchórz na język rosyjski}

Na podstawie analizy lingwistycznej oraz translatorycznej rosyjskiej wersji językowej gry Książę $i$ Tchórz udało się wyodrębnić błędy techniczne (literówki, niezgodność podpisów i dubbingu oraz zły dobór czcionki w podpisach), które często pociągały za sobą błędy tłumaczeniowe różnego rodzaju (pominięcia i przeinaczenia oryginalnego znaczenia).

Jednym z dość często pojawiających się typów usterek w przekładzie gry Książę i Tchórz na język rosyjski są literówki. Zazwyczaj oprócz wprowadzania odbiorcy w lekką konsternację nie mają one istotnego wpływu na przekazanie treści oryginału w języku docelowym. Jest jednak również kilka miejsc, w których błędy tego rodzaju zmieniają pierwotny sens wypowiedzi. Gdy grabarz wspomina Arivalda, mówi: „Как говорят, он был необычным малым". W tłumaczeniu na polski kwestia ta brzmi: „Mówi się, że był niezwykłym małym”. W polskiej wersji językowej grabarz stwierdza, że Arivald był wielkim magiem, więc oryginał został tutaj istotnie zdeformowany.

Czasami różnego rodzaju zabiegi rosyjskich lokalizatorów z grupy 7-ой волк doprowadzały do mniejszych lub większych rozbieżności między oryginałem a jego rusyfikacją. W tej drugiej wersji gry wiele obiektów i osób zostało mylnie podpisanych, np. żebrak - jako jeden z graczy w kości („игрок”) stojących po drugiej stronie ulicy, podczas gdy żebrakiem („нищий”) nazwano kapeć, który mężczyzna ów od czasu do czasu ściąga ze swojej stopy.

Pomyłki w podpisach nie tylko dotyczą obiektów lub osób znajdujących się niedaleko siebie w świecie przedstawionym, ale też wprowadzają obiekty niepojawiające się w grze ani razu. Przykładem tego jest podpis, jakim opatrzono jeden z przedmiotów kluczowych dla rozgrywki - lutnię, na której bohater musi zagrać: „флейта”, czyli po polsku 'flet'. Elementem pozajęzykowym, który negatywnie wpływa na odbiór rusyfikacji gry, 
okazuje się również wielkość czcionki dobranej przez twórców omawianej wersji. Jak można zauważyć na rysunkach zawartych w dalszej części artykułu, rozmiar tej czcionki jest dużo mniejszy niż w polskiej wersji językowej, co sprawia, że utrudnia odbiór podpisów w porównaniu oryginałem.

Krytycy i gracze zgodnie wskazują polski dubbing jako jedną z najważniejszych zalet Księcia i Tchórza. Aktorzy zręcznie oddają charakter postaci, w jakie się wcielają, oraz wypowiadanych przez nie słów. Jeśli chce się zapewnić poziom grywalności zbliżony do wersji oryginalnej, dobra jakość udźwiękowienia produkcji powinna być jednym z najistotniejszych aspektów jej lokalizacji. Niestety, nie można powiedzieć tego o rosyjskiej wersji głosów bohaterów gry. W rusyfikacji nie starano się odtworzyć oryginalnego rysu osobowości poszczególnych bohaterów. Wypowiedzi bardzo często charakteryzuje pozbawiona ekspresji intonacja i wydają się one zupełnie wyrwane z kontekstu sytuacji, w jakiej można je usłyszeć. Oprócz tego w rosyjskiej wersji Księcia i Tchórza błędnie podstawiono głosy lektorów. Wielokrotnie zdarza się, że dany aktor czyta zarówno pytanie zadane przez swoją postać, jak i odpowiedź innego bohatera.

Elementem, którego nie można było zmienić w kodzie gry, jest kolejność następowania po sobie zdań wypowiadanych przez różne postacie. Każdy bohater ma przypisany własny kolor czcionki przedstawiającej wygłaszane przez niego słowa, a kwestie zawsze wyświetlają się nad rozmawiającymi postaciami w kolejności ustalonej przez twórców. Jednym z powtarzających się błędów jest wprowadzenie dwóch wypowiedzi jednej postaci z rzędu, podczas gdy w oryginale były to kwestie dwóch różnych bohaterów. W wyniku tego słowa jednej z postaci pojawiają się również nad jej rozmówcą. Miało to miejsce np. na zakończenie dialogu głównego bohatera $\mathrm{z}$ mnichem napotkanym w karczmie. $\mathrm{W}$ oryginale Galador żegna się z nim słowem: „Smacznego!”, a mnich odpowiada: „Jeszcze jak!”. W rosyjskiej wersji ten dialog brzmi następująco: „Приятного аппетита! [Smacznego]” - „Тогда я пошёл [W takim razie sobie pójdę]”. W przeciwieństwie do poprzedniej sytuacji kwestie są przeczytane przez dwóch różnych aktorów zgodnie z kolejnością wypowiadania się postaci, którym użyczyli oni swoich głosów. Tak skonstruowany dialog sugeruje, że to mnich się żegna, podczas gdy w rzeczywistości pomieszczenie 
opuszcza Galador. Usterki te pozwalają stwierdzić, że osoby tłumaczące kwestie dialogowe oraz czytające je nie miały styczności z grą, a jedynie z tekstem w niej zawartym.

Częstym zabiegiem stosowanym przez rosyjskich lokalizatorów są skrócenia oryginalnych zdań. Zazwyczaj nie zmieniały one wydźwięku danej sceny, a nawet ułatwiały odbiór gry, jak np. w sytuacji przedstawionej na rys. 1 (wypowiedź grabarza w tłumaczeniu na język polski brzmi: „Przeklinam wszystko, co tu znalazłeś”).
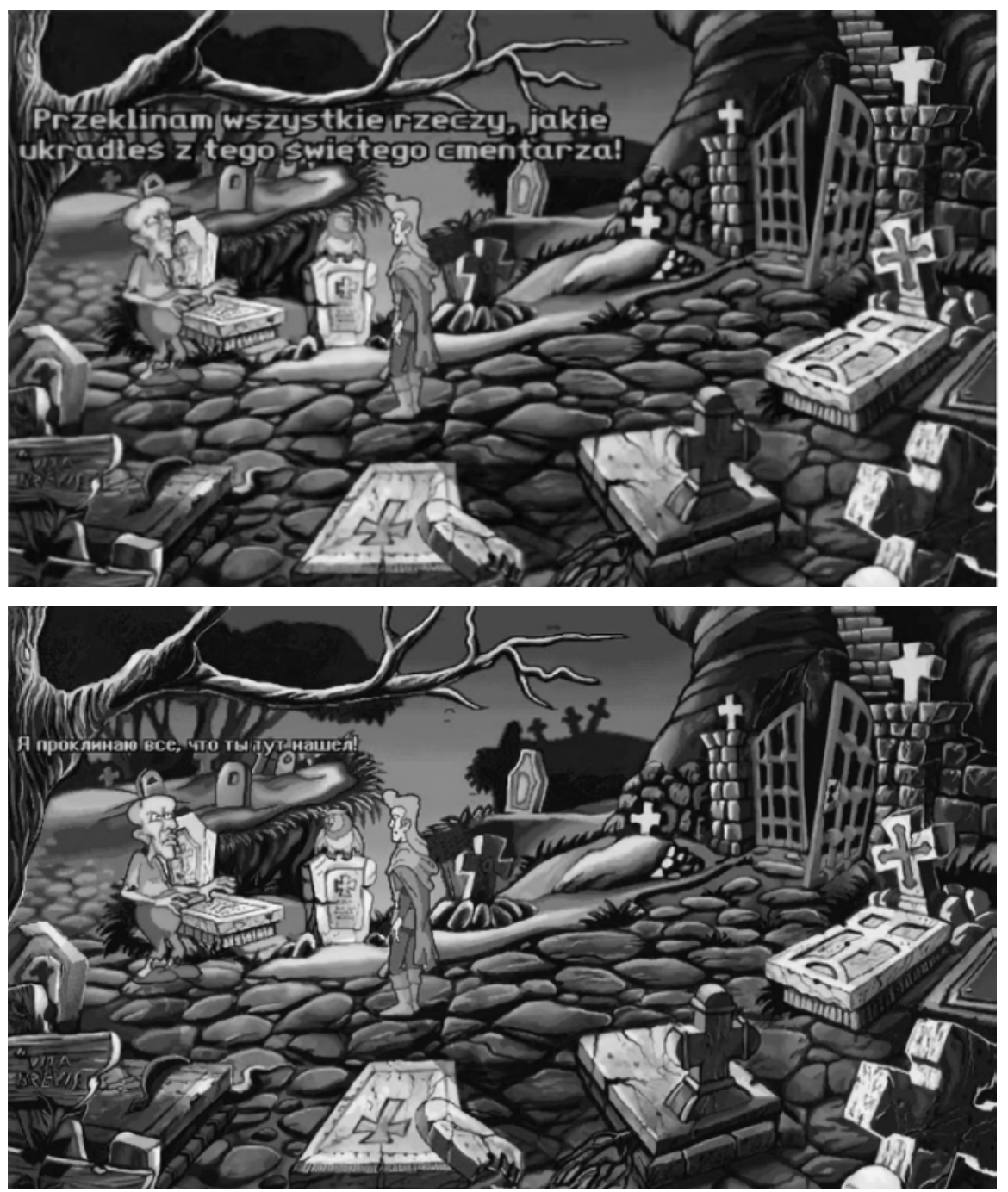

Rysunek 1. Skrócenie oryginalnego zdania w rosyjskiej wersji językowej 
Skrócenie tłumaczenia względem oryginału daje tu odbiorcy szansę na przeczytanie tej kwestii, ponieważ w wariancie rosyjskim wypowiedzi grabarza są artykułowane bardzo szybko i często trudno byłoby je zrozumieć bez podpisów.

Jednakże wiele ze skrótów i pominięć zastosowanych przez lokalizatorów z grupy 7-ой волк doprowadziło do utraty elementów humorystycznych, przez co rusyfikacja gry była o wiele uboższa w tej warstwie niż jej oryginalna wersja. Jest to usterka znacząca ze względu na humorystyczną konwencję Księcia i Tchórza. W jednym z miejsc, gdy Arivald opisuje lokalną karczmę, daje upust swojemu zamiłowaniu do piwa: „Podawali piwo, krasnoludzki spirytus z piwem i pyszną golonkę $\mathrm{z}$ chrzanem gotowaną w piwie. Pod ścianą siedziało piwo, eee, to znaczy bard, i pisał poemat, najczęściej o mnie". W rosyjskiej wersji językowej lapsus pojawiający się w ostatnim zdaniu został pominięty, przez co brakuje również dość uniwersalnego komizmu, jaki zdanie to przekazałoby nawet, jeśli zostałoby przetłumaczone w sposób dosłowny.

Innym przykładem usunięcia elementu humorystycznego jest w wersji rosyjskiej wywód jednego z kupców odnośnie do jego wiary w legendy. Polska i rosyjska wersja tej kwestii zostały zaprezentowane na rys. 2 (w tłumaczeniu na język polski zlokalizowane zdanie brzmi: „Opowiadają tam o ognistych potworach, które po nocach wykradają dzieweczki, a potem w odpowiednim momencie zjawia się rycerz...").

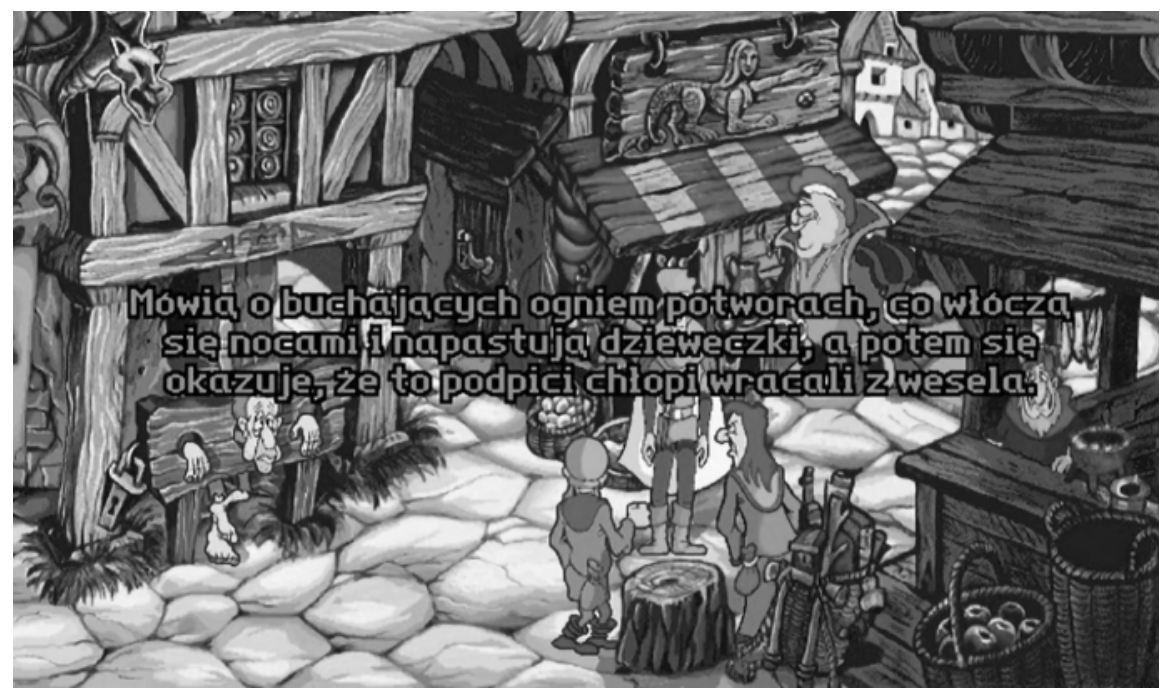




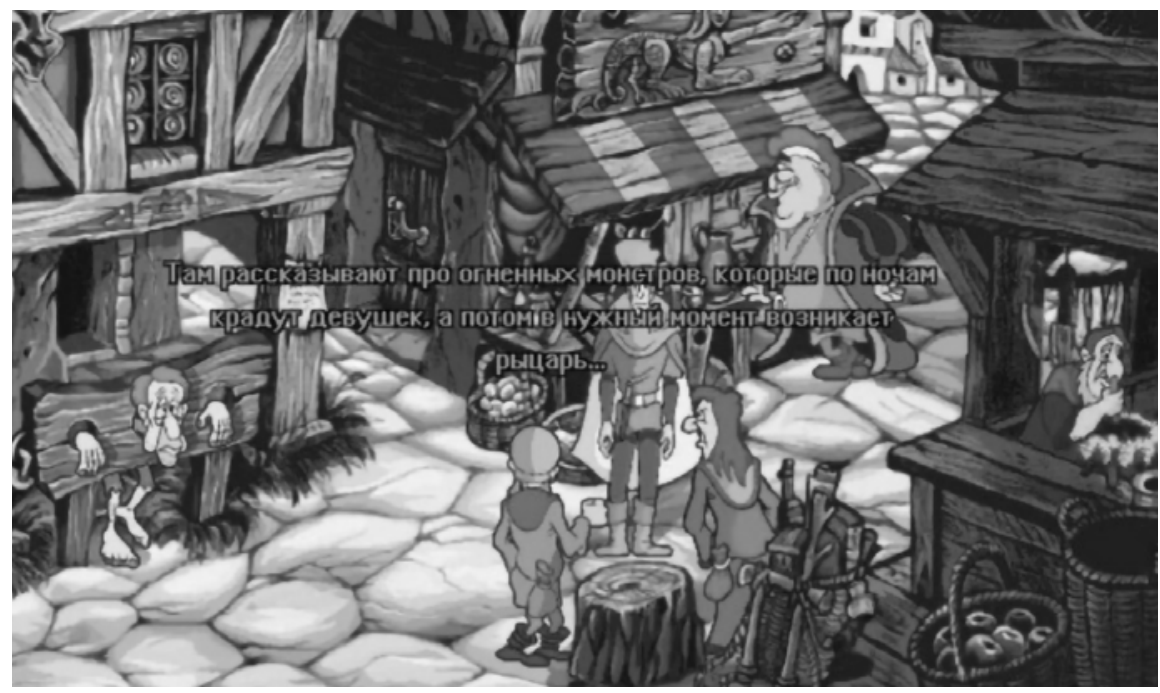

Rysunek 2. Neutralizacja elementu humorystycznego w rosyjskiej wersji gry

Tutaj aspekt humorystyczny został zneutralizowany poprzez usunięcie elementu zaskoczenia pojawiającego się w wersji polskiej.

Pomimo znacznej liczby błędów wariant rosyjski zawiera również elementy dodane, które zwiększają grywalność. W lokalizacji tej mamy do czynienia z kilkoma przykładami transkreacji. Przykładowo, zabiegiem zupełnie zmieniającym wymowę prologu gry jest dodanie pewnego szczegółu, niekoniecznie widocznego na pierwszy rzut oka. Scena trwa jednak ponad pięć minut i każdy, kto gra w wersję rosyjską, a wcześniej grał w polską, na pewno go zauważy.

Otóż szczegół ów to napis „Alkohol” na grzbiecie księgi, na której wspiera się mag Arivald. W polskiej ani w żadnej innej wersji językowej nie występuje ten niewątpliwie humorystyczny akcent.

Ze względu na specyfikę udźwiękowienia w omawianej lokalizacji całkiem inaczej przedstawiona została również postać samego Arivalda. Jedną z charakteryzujących go cech jest to, że w ciągu całej rozgrywki nie stroni on od alkoholu. W polskiej wersji gry nie ma to jednak żadnego wpływu na sposób, w jaki czarodziej się wypowiada. W rusyfikacji styl odgrywania tego bohatera został bezsprzecznie zainspirowany jego czerwonym nosem, tak że często, gdyby nie podpisy, trudno byłoby zrozumieć, co ta postać chce nam w danej chwili powiedzieć. 
Dodatkowym elementem transkreacji jest fakt, że kilka spośród postaci występujących w grze w lokalizacji na język rosyjski cechuje wyraźnie obca dla tego języka wymowa (najłatwiej zauważyć gruziński akcent $u$ jednego $z$ kupców oraz u mnicha - misjonarza).
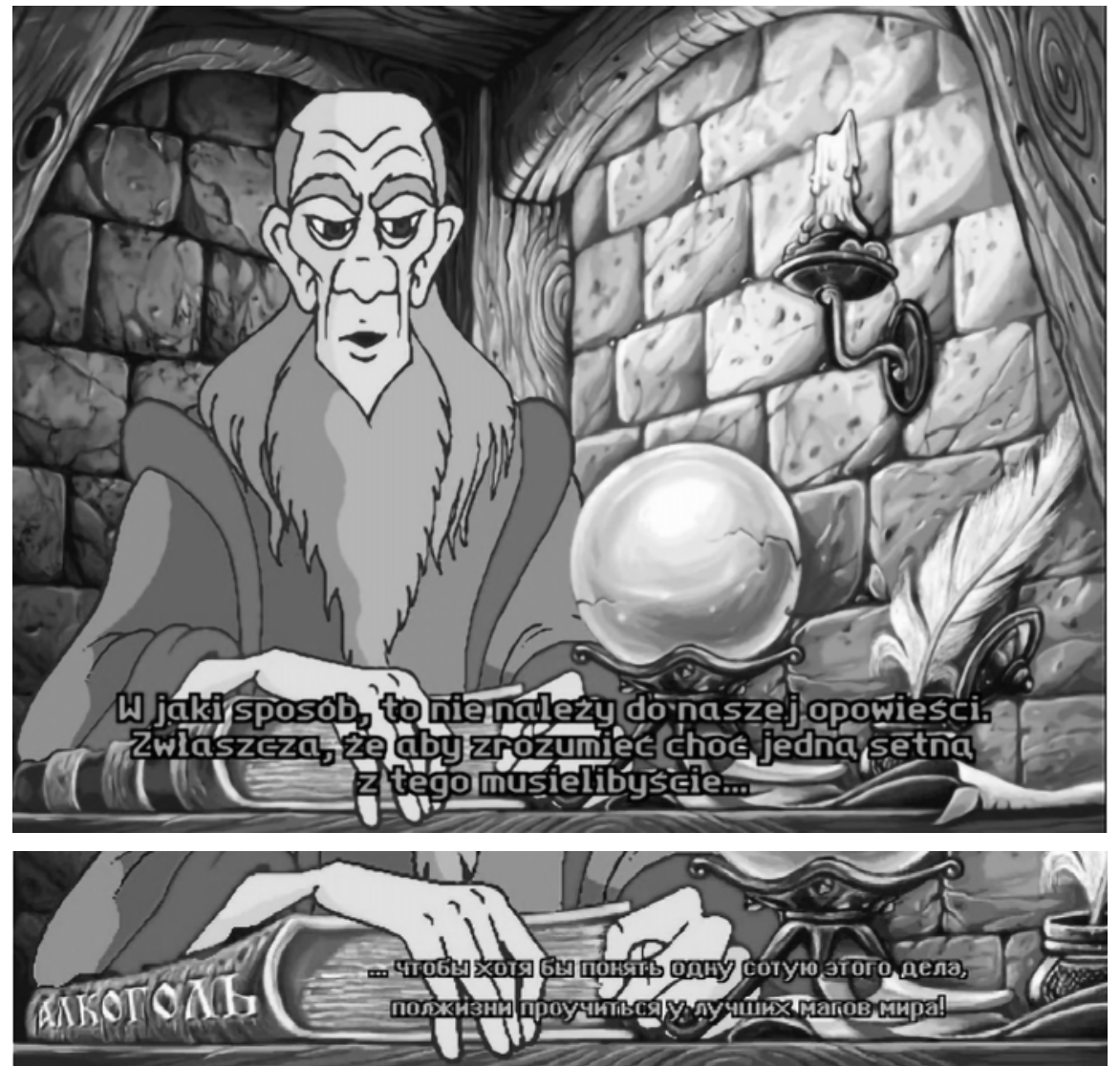

Rysunek 3. Przykład transkreacji w rosyjskiej wersji językowej gry

\section{Wnioski}

Z przeprowadzonej analizy wynika, że w lokalizacji językowej gier wideo bezwzględnie należy wystrzegać się błędów gramatycznych, ortograficznych, niespójności terminologicznej, stosowania niepoprawnych ekwiwalentów tłumaczeniowych, a na poziomie aspektów technicznych - niepoprawnego dopasowania podpisów przedmiotów lub kwestii dialogowych, 
jak również nagrań dźwiękowych, niezgodności podpisów z dubbingiem oraz błędów typograficznych niezwiązanych z ortografią (np. nieusunięcie znaczników kodu źródłowego w tekście ostatecznie wyświetlającym się na ekranie).

Natomiast niektóre inne błędy, np. uproszczenia zdań, pominięcia elementów nacechowanych stylistycznie czy zamiana ich na fragmenty o odmiennym zabarwieniu, choć często postrzegane jako usterki, mogą być akceptowane w zależności od kontekstu. W związku z tym w translacji wolno niekiedy pominąć konkretny element humorystyczny, aby zastąpić go takowym w innym miejscu, które w oryginale miało charakter neutralny (kompensacja tłumaczeniowa). Ze względu na cechy charakterystyczne gier wideo jako tekstów na pierwszy plan w ich przekładzie wysuwa się ekwiwalencja funkcjonalna (pragmatyczna), podczas gdy ekwiwalencja formalna czy nawet semantyczna nie odgrywają tak istotnej roli.

Jak wskazuje część badaczy (np. Czech, 2013), nieścisłości i pominięcia pojawiające się w lokalizacji gier wideo wynikają niekiedy z nieodpowiedniego zapoznania się tłumacza z produkcją. W przypadku lokalizacji Księcia $i$ Tchórza przyczyną mógł być tryb pracy lokalizatorów. Część spośród nich miała zapewne do czynienia wyłącznie z tekstem, wprowadzanym następnie do kodu gry przez innego członka zespołu (na takie praktyki zwraca uwagę m.in. Burtan [2016]).

Niektóre błędy wynikają najprawdopodobniej również z faktu, że w przypadku tłumaczeń amatorskich lub półamatorskich określanych mianem „rusefekacji” nie wykonuje się korekty, która niewątpliwie wychwyciłaby usterki takie jak literówki czy błędy językowe, jak również nieścisłości spowodowane brakiem spójności między słownictwem stosowanym przez różne osoby wchodzące w skład zespołu lokalizującego grę. Wiele z owych niedoskonałości może wynikać ze wspomnianych m.in. przez Dzierźanowską „lenistwa, zadufania we własną wiedzę czy niechlujnego podejścia do powierzonego zadania" (1988, s. 78).

Na zakończenie należy zaznaczyć, że przekłady zaprezentowanej jakości nie są już normą w lokalizacji na język rosyjski (por. Ujutnyj podwalczik, 2015). Zajmują się nią biura tłumaczeniowe i tłumacze z doświadczeniem w tego rodzaju projektach. Opisana powyżej klasyfikacja błędów w lokalizacji językowej gier wideo oraz przykłady takich uchybień mogą jednak posłużyć początkującym adeptom owej sztuki. 


\section{Literatura}

Bernal-Merino, M. Á. (2015). Translation and Localisation in Video Games: Making Entertainment Software Global. New York: Routledge.

Burtan, G. (29 września 2016). Zapomnij wszystko, co wiedziałeś o tłumaczeniach. Do tej polskiej firmy wydawcy gier ustawiają się w kolejce. Online: <http://innpoland.pl/129995,zapomnij-wszystko-co-wiedziales-o-tlumaczeniach>.

Czech, D. (2013). Challenges in video game localization: An integrated perspective. Explorations, 1(1), 3-25.

Donovan, T. (2010). Replay: The History of Video Games. Lewes: Yellow Ant.

Drab, E. (2014). Gry wideo a przekład: nowe pole badań w obrębie tłumaczenia audiowizualnego. Rocznik Przekładoznawczy, 9(1), 101-114.

Dybiec-Grajer, J. (2013). Zmierzyć przekład? Z metodologii oceniania $w$ dydaktyce przekładu pisemnego. Kraków: Universitas.

Dzierżanowska, H. (1988). Przekład tekstów nieliterackich na przykładzie języka angielskiego. Warszawa: PWN.

Grucza, F. (red.) (1978). Z problematyki błędów obcojęzycznych. Warszawa: WSiP.

Hejwowski, K. (2001). Źródła błędów w tłumaczeniu na język ojczysty. W: A. Kopczyński, U. Zaliwska-Okrutna (red.), Język rodzimy a język obcy. Komunikacja, przekład, dydaktyka. Materiały z XXI Sympozjum zorganizowanego przez Instytut Lingwistyki Stosowanej UW i Polskie Towarzystwo Lingwistyki Stosowanej, Warszawa, 29-30 maja 2000 r. (s. 149-159). Warszawa: Wydawnictwo Uniwersytetu Warszawskiego.

Juul, J. (2005). Half-real: Video Games Between Real Rules and Fictional Worlds. Cambridge [Massachusetts]: MIT Press.

Karczewska, D. (2001). O błędach w tłumaczeniu. W: A. Kopczyński, U. Zaliwska-Okrutna (red.), Język rodzimy a język obcy. Komunikacja, przekład, dydaktyka. Materiały z XXI Sympozjum zorganizowanego przez Instytut Lingwistyki Stosowanej UW i Polskie Towarzystwo Lingwistyki Stosowanej, Warszawa, 29-30 maja 2000 r. (s. 129-135). Warszawa: Wydawnictwo Uniwersytetu Warszawskiego.

Kuipers, E.-J. (2010). Lokalizacja gier komputerowych - czyżby dziecinnie proste? Nowe perspektywy w szkoleniu tłumaczy pisemnych. Homo Ludens, 2(1), 77-86. 
Kutera, T. (14 lipca 2014). Już niedługo będzie można zagrać w „Księcia i Tchórza" na współczesnym sprzęcie. Online: <http://polygamia.pl/ juz-niedlugo-bedzie-mozna-zagrac-w-ksiecia-i-tchorza-na-wspolczesnym-sprzecie>.

Lurkmore.to (11 czerwca 2017). Русефекации [Rusefekacja]. Online: $<$ http://lurkmore.to/Русефекации>.

Mosin, М. (Мосин М.) (14 stycznia 2015). Вспоминаем тех, благодаря кому у нас были компьютерные игры на русском языке [Wspominamy tych, dzięki którym mieliśmy gry komputerowe w języku rosyjskim]. Online: <https://xakep.ru/2015/01/14/old-translators>.

O'Hagan, M., Mangiron, C. (2013). Game Localization: Translating for the Global Digital Entertainment Industry. Amsterdam-Philadelphia: John Benjamins Publishing Company.

Pieńkos, J. (2003). Podstawy przekładoznawstwa. Od teorii do praktyki. Kraków: Kantor Wydawniczy „Zakamycze”.

TVGRYpl (3 września 2017). Pierwsza naprawdę udana polska gra? „Książę i Tchórz" po długich latach. Online: <https://www.youtube.com/ watch?v=bnKK_tqGWJI>.

Ujutnyj podwalczik (Уютный подвальчик) (24 czerwca 2015). Почему игры стали плохими? [Dlaczego gry są teraz złe?]. Online: <https:// www.youtube.com/watch?v=6UOGKDR2RLI>.

Data dostępu od źródeł internetowych wykorzystanych w tekście: 30 grudnia 2017. 
mgr Dominik Kudła - doktorant na Wydziale Lingwistyki Stosowanej Uniwersytetu Warszawskiego oraz wykładowca w Instytucie Komunikacji Specjalistycznej i Interkulturowej tamże. Jego zainteresowania naukowe obejmują przekładoznawstwo, lokalizację gier wideo, dydaktykę tłumaczenia, kontakty językowe, język piłki nożnej oraz badania okulograficzne

\title{
Jak nie tłumaczyć gier na rosyjski. Analiza lokalizacji gry Książę i Tchórz z języka polskiego na język rosyjski
}

\begin{abstract}
Abstrakt: Artykuł przedstawia problematykę błędów pojawiających się w lokalizacji językowej gier wideo. Do omówienia głównych aspektów tego zagadnienia została wybrana polska gra komputerowa Książę i Tchórz (1998, Metropolis) oraz jej wersja rosyjska (Галадор - Проклятие принца; 1999, 7-ой волк). Szczególną uwagę poświęcono również rozgraniczeniu terminów "lokalizacja językowa" oraz „tłumaczenie" gier wideo, klasyfikacji najistotniejszych błędów w tym rodzaju przekładu oraz ich możliwym przyczynom.
\end{abstract}

Słowa kluczowe: gry wideo, lokalizacja językowa, błędy tłumaczeniowe, point-and-click 